\title{
Legal Considerations Settlement Of Criminal Acquisition of Land
}

\section{Hapshary Noor Diansaputri *) and Aryani Witasari**)}

*) Student of Master of Law, Faculty of Law, Sultan Agung Islamic University, Semarang, email: hapsharynd@gmail.com

**) Faculty of Law, Sultan Agung Islamic University, Semarang

\begin{abstract}
One of the land conflicts that often occurs is the grabbing of land belonging to other people, whether intentional or unintentional, either by an individual or by a group of people. Land grabbing is a form of taking the rights of others against the law. This study aims to identify and analyze the factors that cause land grabbing, to identify and explain the form of legal arrangements for the crime of land grabbing and to analyze judges' legal considerations on the settlement of land grabbing crimes. This study uses a normative juridical approach, which is a legal research conducted by examining library materials or secondary data as the basic material for research. The theory used to analyze law enforcement theory and dispute resolution theory. Based on the research, the conclusion is: The factors driving the crime of land grabbing are the lack of awareness of the importance of legal protection of land ownership or control rights among the community, the existence of parties with certain motives against land that are considered to have no legal protection. Crimes against land grabbing are also regulated in the Criminal Code (KUHP), which is regulated in several articles in the KUHP, including: Article 167 of the Criminal Code and Article 385 of the Criminal Code. In deciding a case, a judge must consider sociological, philosophical and juridical aspects.
\end{abstract}

Keywords: Judge's Consideration, Crime, Land Grabbing

\section{Introduction}

Land is a gift from God Almighty, which has a very important function for human life. Land has a very close relationship with humans, everyone always needs land not only in this world, even humans need a piece of land to die. Bernhard Limbong stated that land is a basic human need, from birth to death. That humans need land for shelter and a source of life. So cosmologically, land is a place where people live, where they work and live, where they come from and where they will go. In this case, land has economic, social, cultural, political and ecological dimensions. ${ }^{1}$

In human life, the existence of land cannot be separated from all human actions, because land is a place for humans to carry out and continue their life. ${ }^{2}$ As citizens of Indonesia, we have land rights which include: property rights, land use rights, building use rights, usage rights, lease rights for buildings, rights to open land and collect forest products. In the UUPA, property rights are the strongest and fullest inherited rights to land that can be owned by people over land. ${ }^{3}$

Proof of ownership of land can be proven by means of a land certificate which is the strongest proof of rights for the land owner. ${ }^{4}$ Land registration activities are

\footnotetext{
${ }^{1}$ Bernhard Limbong, 2012, Konflik Pertanahan, Pustaka Margaretha, Jakarta, p. 1-2.

${ }^{2}$ Andrian Sutedi, 2007, Peralihan Hak Atas Tanah dan Pendaftarannya, Sinar Grafika, Jakarta, p. 31.

3Urip Santoso, 2015, Perolehan Hak Atas Tanah, Prenamedia Group, Jakarta, p. 37.

${ }^{4}$ Ibid p. 167
} 
indispensable. The goal is that land rights holders can easily prove their rights to the land they control and obtain legal certainty regarding land rights. ${ }^{5}$

But in reality, even land registration cannot guarantee that a certified land can be free from land conflicts. Land conflicts according to the hamzah quoted by Hambali Talib, are termed offenses in the land sector which in general can be divided into 2 (two) parts, which include:

1. Land conflicts that are regulated in the codification of criminal law, namely conflicts (offenses) which are regulated in several articles scattered in the codification of criminal law;

2. Land conflicts that are regulated outside the codification of criminal law, namely land conflicts (offenses) specifically related to land legislation outside the codification of criminal law. ${ }^{6}$

One of the land conflicts that often occurs is the use of land without the rightful permit, or what is commonly known as the grabbing of land belonging to other people, whether intentional or unintentional, either by individuals or by a group of people. Land grabbing is not something new in Indonesia.

The word encroachment itself can be defined as the act of taking rights or property arbitrarily or by disregarding laws and regulations, such as occupying someone else's land or house, which is not their right. The act of taking land illegally is an act against the law, which can be classified as a criminal act. ${ }^{7}$

In general, the term land grabbing can be interpreted as an act of controlling, occupying or taking over other people's land against the law or against rights or violating applicable regulations. Confiscation of land is a type of criminal act that occurs in society. There are various problems of land grabbing that often occur, such as physical land occupation, land cultivation, sale of land rights and others. ${ }^{8}$

Criminal acts of land grabbing must be immediately resolved by enforcing the law in the community. A lawless society can never be a good society. Even in traditional societies, there must be laws with forms and patterns that are in accordance with the level of civilization of that society. ${ }^{9}$ The law regulates all actions that should not be taken along with the sanctions if they are violated, so that people will be more careful in acting.

In an effort to enforce the law on the crime of land grabbing, the values of justice must be prioritized, apart from legal certainty and benefit. Law enforcement and justice in a fair or just legal process is the enforcement guaranteed by the 1945 Constitution of the Republic of Indonesia which provides protection and benefits for every citizen in the context of upholding constitutional supremacy as the basic law.

\section{Research Methods}

\footnotetext{
5 Ibid p. 157

${ }^{6}$ Hambali Thalib, 2005, Penyerobotan Tanah Secara Tidak Sah dalam Perspektif Pidana, Ukhuwah Grafika, Makassar, p. 27.

7Ivor Ignasio Pasaribu, Penyerobotan Tanah Secara Tidak Sah dalam Perspektif Pidana. Accessed fromhttp://www.hukumproperti.com April 6, 2020

8 Ibid

${ }^{9}$ Bushar Muhammad, 1961, Pengantar Hukum Adat, Balai Buku Ichtiar, Jakarta, p. 39.
} 
The approach method used in this research is the normative juridical approach. According to Soerjono Soekanto, a normative juridical approach is a legal research conducted by examining library materials or secondary data as the basic material for research by conducting a search on regulations and literature related to the problem under study. ${ }^{10}$ This research is specified as an analytical descriptive study, namely by describing the applicable laws and regulations associated with legal theories and practice of implementing positive law relating to problems, ${ }^{11}$ because in this study the author tries to describe the existing realities or existing facts and describe a problem that exists in the case of land grabbing.

The type of data used is secondary data. Secondary data is data obtained from various existing sources. Secondary data obtained through literature study. Literature study is the collection of data sourced from books, literature and opinions of legal experts related to this research, or other sources in the field to support the success and effectiveness of research, namely by separating outlines between primary data and secondary data. ${ }^{12}$ The data analysis method used is descriptive qualitative, namely the decomposition of the data analysis which is based on the information obtained from the respondents in order to achieve clarity of the issues being discussed. From this analysis, it can be seen that the effectiveness of the legal system which is educative for the public in knowing the legal review of land grabbing is viewed in the aspect of criminal law.

\section{Results And Discussion}

\subsection{Factors which Cause Land Grabbing}

Confiscation of land is an illegal act in which a person enters the land owned by another person without the right, or causes someone or causes another person or object to enter another person's land or causes a certain person or object to remain in other people's land. As one of the most valuable assets, land is very prospective in business and investment. Considering that the price is relatively stable and tends to increase from year to year, it is not surprising that the need and demand for land will continue to increase. This is one of the reasons why land grabbing occurs a lot.

In land disputes between individuals, legal entities, or institutions that do not have broad socio-political impacts. One of the contributing factors is the failure of communication between parties or because the parties are still unfamiliar with problems in the land sector. ${ }^{13}$

The factors driving the criminal act of land grabbing are the lack of awareness of the importance of legal protection of land ownership or control rights among the community, the existence of parties with certain motives against land who are deemed to have no legal protection. In addition to this, the case that

\footnotetext{
${ }^{10}$ Soerjono Soekanto and Sri Mamudji, 2001, Penelitian Hukum Normatif(Suatu Tinjauan Singkat), Rajawali Pers, Jakarta, p. 13-14.

11Ronny Haniatjo Soemitro, 1990, Metode Penelitian Hukum dan Jurumetri, PT Ghalia Indonesia, Jakarta, p. 97-98

${ }^{12}$ Sugiyono, 2013, Metode Penelitian Kuantitatif, Kualitatif dan R\&D, Alfabeta, Bandung, p.205.

${ }^{13}$ R.Resvitasari, "Penyelesaian Tanah Non Litigasi di Kab. Konawe Sulawesi Tenggara”, Jurnal Hukum, eprints@Undip.ac.id, 2009.p.7.
} 
occurs in land issues is that there is physical control by another person or other party over the land object where the owner of the object is actually a legal party as the owner because he has a certificate of ownership rights over the land object. However, the legal owner abandoned the land so that it was occupied by someone else and this is what happened in the case of land grabbing in Gorontalo.

Factors that also hinder law enforcement against perpetrators of criminal acts of land grabbing, namely due to the lack of criminal threats so that there are still many individuals who do not feel deterred and want to take advantage of the existing situation without thinking about others, while in law enforcement factors there are not enough members or teams. investigators who are truly competent in handling the case so that the investigation process is a little constrained. The failure of law enforcement is also influenced by the incompatibility and / or incompatibility between components, the components of the law that are enforced, often vertically and horizontally out of alignment. ${ }^{14}$

\subsection{Forms of Legal Arrangements for the Crime of Land Grabbing}

The criminal act of confiscation of land by a person or group of people against a land belonging to another person can be interpreted as an act of controlling, occupying or taking over the land belonging to another person can be sued according to civil law or according to criminal law.

Government Regulation in Lieu of Act No. 51 of 1960 concerning Prohibition of Use of Land without Authorized Permit or Proxy states that the use of land without a permit with the right or legal proxy is an act which is prohibited and is punishable by criminal penalties (Article 2 and Article 6).

Crimes against land grabbing are also regulated in the Criminal Code (KUHP), which is regulated in several articles in the KUHP, including:

Article 167 KUHP, Article 167 KUHP contains several elements, namely:

1. Whoever;

2. Their element huhng by giving or promising something, by abusing power or dignity, by means of violence, threats or misdirection, or by providing opportunities, means or information, deliberately encouraging others to commit acts;

- The element of forcing into a house, room or closed yard that is used by other people or is there against the law;

- Elements against the law;

- The element of the request which is entitled or the order does not go away immediately;

The perpetrator can only be proven to have deliberate intent on the elements of the criminal act regulated in Article 167 paragraph (1) of the Criminal Code, if in a court hearing the perpetrators it can be proven that:

a. The perpetrator has willed to illegally enter by force;

b. The perpetrator knew that what he had entered by force was a residence or a closed room or courtyard used by another person;

\footnotetext{
${ }^{14}$ Achmad Budi Waskito, Implementasi Sistem Peradilan Pidana Dalam Perspektif Integrasi, Jurnal Daulat Hukum Vol 1. No. 1, March, 2018. p. 299
} 
c. The perpetrator wished to remain there;

d. The perpetrator has wanted not to leave immediately after a request from the person entitled to the residence, room or enclosed yard.

What is also considered as forced entry is according to paragraph two:

a. Those who enter by breaking, climbing, wearing fake keys, fake orders or fake official clothing or

b. Those who do not know who are entitled and other than because they are wrong, enter that place and are caught at night.

From the formulation of the criminal provisions stipulated in Article 167 of the Criminal Code above, one can know that what is regulated in it is actually only one criminal act, namely the so-called uisvredebreuk crime or interference with the freedom of residence. ${ }^{15}$

Article 385 of the Criminal Code, which is a crime of embezzlement of the right to immovable property, such as land, houses and rice fields. This crime is commonly referred to as stellionaat crime, which carries a maximum imprisonment of four years.

In order for a defendant to be subject to this article, the defendant must have clearly done the following:

a. The defendant intended to benefit himself or another person with malicious rights (illegally)

b. The defendant has sold; exchange or mean with a creditverband the rights to use the land of the sons over land owned by the State or land owned by particulars or buildings, jobs, plants or sprinkles on native land use rights

c. The defendant knew that it was someone else who was entitled or had the right there

d. The defendant did not inform the other party that the land there was a creditverband

e. The defendant did not inform the other party that the land had been pawned

f. The defendant pawned or leased someone else's land

g. The defendant had sold or exchanged the land that was being pawned to another person by not informing the interested party about it.

h. The defendant had leased the land for a mob, but he was aware that the land had previously been leased to someone else.

Based on the above rules, Article 167 and Article 385 of the Criminal Code are articles that are often used by investigators (Police) and Public Prosecutors (Prosecutors) to charge "perpetrators of land grabbing" and are categorized as criminal acts. In particular Article 385 paragraph (1) of the Criminal Code which reads: "whoever with the intention of benefiting himself or another person unlawfully sells, exchanges or burdens with a crediet verband of rights to Indonesian land, a building, building, planting or seeding, whereas in fact it is known that other people have or participate in having rights over it".

\subsection{Legal Considerations of Judges in Settlement of Crime of Land Grabbing}

\footnotetext{
${ }^{15}$ Lamintang and Theo Lamintang, 2010, Delik- Delik Khusus Kejahatan Terhadap Kepentingan Hukum Negara, Sinar Grafika, Jakarta, p. 577.
} 
The case of land grabbing is not something new to happen in Indonesia. Whereas the act of illegally grabbing land is an act against the law, which can be classified as a criminal act. Any act related to land grabbing is a crime that must be eradicated, however, it is still based on legal procedures and prevailing laws and regulations.

Law enforcement in cases of land grabbing through criminal justice institutions (courts) is closely related to judges' decisions / court decisions, because it is through a judge's decision that criminal sanctions against perpetrators are applied.

The judge's decision can be obtained by interpreting the applicable provisions, then determining the law, after which the judge applies the violated articles. In trying someone, the judge must be open to constructive criticism and truth, and must not base decisions on his own feelings. Judges must also really pay attention to and understand the circumstances, events or facts of the occurrence of a criminal act, the background factors of the accused, the consequences of the punishment imposed and the values of life that develop in society.

According to Act No. 48 of 2009 concerning Judicial Power, the authority of judges in deciding a case has three aspects, namely:

a. Receiving, reports that have been submitted to the judge, seeking information and evidence.

b. Checking, looking carefully at the defendant's case file.

c. Decides, the sentence of a case that is being examined and tried by the judge.

When exercising this authority, especially in adjudicating a judge's decision, it is the crown and culmination of a case that is being examined and being tried by the judge. ${ }^{16}$

So the judge in making a decision must pay attention to all aspects in it, namely the indictment, the facts of the judge at trial, the condition of the community at trial. Apart from that, in accordance with Article 183 KUHAP a judge in imposing such a sentence is, unless with at least two valid evidence, the judge is convinced that a criminal act has actually occurred and the defendant is guilty of committing it. The provisions of Article 183 KUHAP aim to guarantee legal certainty for a person (explanation of Article 183 KUHAP). At least two pieces of evidence that are valid, have a purpose, namely at least two pieces of evidence that are valid according to the Criminal Procedure Code, evidence that is valid according to the Criminal Procedure Code.

The Criminal Procedure Code is regulated in Article 184 paragraph (1) of the Criminal Procedure Code regarding the legal evidence means:

a. Witness statement

b. Expert Statement

c. Letter

d. Instructions

e. Statement of the defendant or something that is generally known so it does not need to be proven. ${ }^{17}$

\footnotetext{
16Rimdan, 2012, Kekuasaan Kehakiman, Jakarta, Pramedia Group, p. 36.

${ }^{17}$ Satjipto Rahardjo, 1998, Bunga Rampai Permasalahan dalam Sistem Peradilan Pidana, Jakarta,

Pusat Pelayanan Keadilan dan Pengabdian Hukum, p. 11.
} 
Thus, to be able to see whether the judge's decision is in accordance with the criminal act charged by the Public Prosecutor, according to Sudarto the judge's decision is the culmination of a criminal case, so the judge must consider other aspects apart from the juridical aspect, so that the decision The judge fully reflects the following sociological, philosophical and juridical values:

a. Juridical Considerations

The juridical consideration means that the judge bases his decision on the provisions of statutory regulations in a formal manner. Judge juridically, may not impose the sentence unless with at least two valid evidence, so that the defendant is guilty of committing it (Article 183 KUHAP). The valid evidence means: (a) Witness statement; (b) Expert Statement; (c) Letter; (d) Instructions; (e) A statement by the Defendant or something which is generally known so that it does not need to be proven (Article 184). Apart from that, it was also considered that the defendant's actions violated the formal law and fulfilled the elements of the criminal act committed.

b. Philosophical Considerations

The philosophical consideration means that the judge considers that the sentence imposed on the defendant is an attempt to improve the behavior of the defendant through the process of punishment. This means that the philosophy of punishment is fostering the perpetrator of the crime so that after the convict leaves the correctional facility, he will be able to improve himself and not commit a crime again. Philosophical considerations, namely considerations or elements that emphasize the value of justice of the defendant or victim. ${ }^{18}$ Meanwhile, according to Bagir Manan, reflecting the philosophical values or values contained in the ideals of law (rechtsidee) is needed as a means of ensuring justice. Justice is generally defined as an act or just actor, while fair is impartial, does not take sides with the right.

c. Sociological Considerations

Sociological considerations mean that the judge in imposing a sentence is based on the social background of the defendant and observes that the punishment imposed has benefits for the community. Apart from the background of the defendant, a consideration that cannot be ignored is the impact experienced by the community due to the crime committed and the condition of the community at the time the crime was committed. And through sociological considerations, the judge saw the things that were incriminating and the things that made it easier for the defendant, then the defendant also admitted frankly and regretted his actions.

\section{Closing}

Crimes against land grabbing are also regulated in the Criminal Code (KUHP), which is regulated in several articles in the KUHP, including: Article 167 of the Criminal Code and Article 385 of the Criminal Code. The factors that drive the occurrence of criminal acts of land grabbing are the lack of awareness of the

18M. Yahya Harahap, 2012, Pembahasan Permasalahan dan Penerapan KUHAP Penyidikan dan Penuntutan, Jakarta, Sinar Grafika, p. 20. 
importance of legal protection of land ownership or control rights among the community, the existence of parties with certain motives against land that are deemed to have no legal protection, lack of criminal threats so that there are still many unscrupulous persons. who do not feel deterred and want to take advantage of the existing situation without thinking about anything else. In deciding a case, a judge must consider sociological, philosophical and juridical aspects. The juridical consideration means the judge bases his decision on the provisions of statutory regulations in a formal manner. There are philosophical considerations that discuss truth and justice for the accused victim in the form of imposing criminal sanctions for two months, thereby exposing philosophical considerations by realizing a sense of justice for the victim and in particular for society in general.

There are still many people who do not understand the possibility of crimes against land in the form of land grabbing. For this reason, efforts that can be made in the context of overcoming crimes against land include preventive and repressive measures. The most important thing in anticipating the possibility of crimes against land is that as soon as possible registering the lands that are legally and clearly controlled by the concerned institution (BPN) in order to realize legal certainty of land rights and minimize the possibility of crimes against land.

The criminal legal process, which can only punish the perpetrators of land grabbing, does not provide legal certainty for landowners, so that the invaders can continue to control the land that is taken over. For this reason, land owners are advised to exercise control over the land they own, such as fencing the land and cultivating it. This is meant so that if there are people or parties who are not the owners, they will stop their intention to enter and or take over the land.

\section{References}

\section{Books:}

[1] Andrian Sutedi, 2007, Peralihan Hak Atas Tanah dan Pendaftarannya, Sinar Grafika, Jakarta

[2] Bernhard Limbong, 2012, Konflik Pertanahan, Pustaka Margaretha, Jakarta

[3] Bushar Muhammad, 1961, Pengantar Hukum Adat, Balai Buku Ichtiar, Jakarta

[4] Hambali Thalib, 2005, Penyerobotan Tanah Secara Tidak Sah dalam Perspektif Pidana, Ukhuwah Grafika, Makassar

[5] Lamintang and Theo Lamintang, 2010, Delik- Delik Khusus Kejahatan Terhadap Kepentingan Hukum Negara, Sinar Grafika, Jakarta

[6] M. Yahya Harahap, 2012, Pembahasan Permasalahan dan Penerapan KUHAP Penyidikan dan Penuntutan, Jakarta, Sinar Grafika

[7] Rimdan, 2012, Kekuasaan Kehakiman, Jakarta, Pramedia Group

[8] Ronny Haniatjo Soemitro, 1990, Metode Penelitian Hukum dan Jurumetri, PT Ghalia Indonesia, Jakarta

[9] Satjipto Rahardjo, 1998, Bunga Rampai Permasalahan dalam Sistem Peradilan Pidana, Jakarta, Pusat Pelayanan Keadilan dan Pengabdian Hukum

[10] Soerjono Soekanto and Sri Mamudji, 2001, Penelitian Hukum Normatif (Suatu Tinjauan Singkat), Rajawali Pers, Jakarta

[11] Sugiyono, 2013, Metode Penelitian Kuantitatif, Kualitatif dan R\&D, Alfabeta, Bandung 
[12] Urip Santoso, 2015, Perolehan Hak Atas Tanah, Prenamedia Group, Jakarta

\section{Regulations:}

[1] Criminal Code

[2] Criminal Procedure Code

[3] Act No. 5 of 1960 regarding Basic Agrarian Principles

[4] Act No. 30 of 1999 concerning Arbitration and Alternative Dispute Resolution

[5] Government Regulation in Lieu of Act No. 51 of 1960 Concerning the Prohibition of Using Land without the Right Permit or Proxy

\section{Journals:}

[1] Achmad Budi Waskito, Implementasi Sistem Peradilan Pidana Dalam Perspektif Integrasi, Jurnal Daulat Hukum Vol 1. No. 1 March 2018

[2] R.Resvitasari, "Penyelesaian Tanah Non Litigasi di Kab. Konawe Sulawesi Tenggara”, Jurnal Hukum, eprints@Undip.ac.id, 2009

\section{Internet:}

[1] Ivor Ignasio Pasaribu, Penyerobotan Tanah Secara Tidak Sah dalam Perspektif Pidana. Accessed from http://www.hukumproperti.com April 6, 2020 